\title{
Western Sport and Spiritualism
}

\author{
Jerzy Kosiewicz
}

Josef Pilsudski University of Physical Education in Warsaw, Poland

\section{ABSTRACT}

Sport activity of achievement-oriented (professional, Olympic, spectacular character) is first of all exposition of rivalry and striving for variously understood sports success (resulting from measurable or discretionary criteria). It refers to winning a competition or taking another expected place as well as to other forms of satisfaction, such as financial gratification or social (political, ethnic, professional) recognition. Spirituality is here neither an aim, nor an expected value - it constitutes rather an additional or redundant quality. A competitor focuses his/her attention first of all on the main aim assumed in planned or current rivalry. Emotional sensations which are experienced by athletes before, during or after competitions testify to mental and emotional stress which accompanies sports combat.

It is also difficult to associate spirituality or spiritualism with sport for all like, for example, that of health-oriented character - sport of the disabled, physical education, sport of playful character or physical recreation. That difficulty results from the fact that neither spiritualism, nor spirituality inspires for physical activity in the abovementioned fields; neither spiritualism, nor spirituality is the outcome of activity in the realm of sport for all.

Exceptions are constituted by ancient Olympic Games as well as by some experiences connected with recreational forms of tourism mediated through achievement-oriented sport (also by pre-Columbian Native American societies and Maoris aboriginal population of New Zealand).

For example Hellenic Olympic Games were a highly spiritualized form of sports rivalry - including also rivalry in the field of art, and especially in the field of theatre. They were one of numerous forms of religious cult - of worshipping chosen gods from the Olympic pantheon. On the other hand, during mountain hiking and mountain climbing there can appear manifestations of deepened spirituality characteristic for the object of spiritualization of non-religious, quasi-religious or strictly religious qualities.

I would like to explain - at the end of this short abstract - that spiritualism (which should not be confused with spiritism) is - generally speaking - first of all a philosophical term assuming, in ontological and axiological sense, that spiritual reality, self-knowledge, consciousness or mental experiences are components of the human being - components of a higher order having priority over matter. They constitute, in the anthropological context, beings of a higher order than the body.

Spiritualism according to its popular interpretation means spirituality. Qualities which are ascribed to that notion in particular societies can be determined on the basis of empirically oriented sociological research. They make it possible to determine various ways of interpreting and understanding that notion as well as views or attitudes connected with it. 


\section{Spiritualism versus spirituality - preliminary considerations}

In my paper concerning connections between Western sport and spiritualism I limited myself to discussing Western sport, because I do not feel properly prepared for considerations on, for example, the role of sport in native American societies in pre-Colombian America, among Maoris - the aboriginal population of New Zealand - or for commentaries on relations taking place between contemplation and spiritual (cultural, religious, philosophical) perfection in the field of martial arts. I prefer, for competence-related reasons, to focus my attention on contemporary European (and especially Olympic) sport in the context of the abovementioned problems.

My presentation has a sketchy character, adapted to requirements for a conference paper. Even when later it is considerably extended in its version intended for publication - which will make it at least twice as longer - its sketchy and simultaneously introductory character will be still all too visible if we compare it with an extensive monograph on that topic which I may write in the future.

In the title I used the expression "spiritualism". I have also inserted in the text the term "spirituality." Both terms derive from the Latin adjective spiritualis. The second term, namely "spirituality," I treat as a general and more colloquial one. Spiritualism (which should not be confused with spiritism) is - generally speaking - first of all a philosophical term assuming, in the ontological and axiological sense, that spiritual reality, self-knowledge, consciousness and mental experiences are components of the human being components of a higher order having priority over matter. They constitute, in the anthropological context, beings of a higher order than the body.

On the foundations of philosophical anthropology spiritualism opposes the materialist conception of man. An extreme form of spiritualism assumes that the human being is solely or primarily a spirit and that his/her connection with the body is something accidental or even feigned. Such a viewpoint is characteristic for some views of Plato, Neo-Platonians and Augustine's disciples, who referred to Orphic anthropology (Krokiewicz, 2000, pp. 7-78; Kosiewicz, 2007, pp. 18-37).

On the other hand, spiritualism understood in a moderate way assumes the existence of two substances - the spiritual and the material. Reason and freedom are qualities of the first, while the second is characterized by extension and movement. The moderate version assumes that the human individual consists of the two connected elements - the soul and the body. According to that standpoint representations and ideas are manifestations of intellectual experience, and acts of will and other mental experiences result from activity of the soul, which means that they can not be reduced to physiological phenomena (Kosiewicz, 2000, p. 137). That standpoint is characteristic also for Christian anthropology.

Simon Robinson claims that human spiritualism concerns practice, experience and faith that are indispensable in psychological and physical relations with other subjects. It is not - in his opinion simplified and superficial knowledge about people but the consciousness which is focused on its own existence and, at the same time, on reflexive dialogue with others. It requires simultaneously intimacy and distance in interpersonal relationships in order to maintain both one's own identity and the identities of others. Human spiritualism is marked by respecting the subjectivity of other people and by having confidence in oneself, and by trust in the changes that the future might bring as well. It depends on the approval of the meaning of the aims we choose.

From Robinson's perspective spiritualism is both person centred and other centred, it develops in realistic situations through dialogue and practical by means of dynamic and risk related interactions (for instance during driving a car). It is both interdisciplinary and holistic in nature. It is also inclusive. It accepts all institutional religions as a particular manifestation of spiritualism (Robinson, 2007a, p. 35-37).

Elsewhere the same author adds that spiritualism is not restricted to the religions existing in a formal sense only but it also is formed within the limits of extra-confessional communities and social institutions. It assumes the existence of diverse forms of spirituality. Robinson notices that the interest in spiritualism in 
relation to well-being, health and personal development is becoming deeper and deeper currently. It has become an object of research for various organisations and social sciences, and the basis of individual experiments (Robinson, 2007b, p. 20).

Robinson claims that spiritualism may be examined from religious, ethical and psychological points of view (Robinson, 2007a, pp. 34-37). In my opinion this belief is too reductive because the assumptions and questions connected with spiritualism may be analysed in the light of sociology and philosophy as well. This last theoretical perspective is the underlying reason for the statements contained in the presented article, even if religious or ethical views are presented. Religious spiritualism (and its links with sport) is discussed in the text from the point of view of the philosophy of religion that is to say from the point of view of this part of philosophy which is independent, extra-confessional and not entangled in ideological links with any concrete religion. Spiritualism as an expression of spiritual, intellectual or intuitive activity, or even some ethical mission in relation to sport is considered in the above-mentioned text in the context of ethics treated as a branch of philosophy only but not in the light of the assumptions of the sociology of morality or the psychology of morality or moral conceptions of some religion and the theology connected with it.

In the first part of my text I am going to focus mainly on considerations concerning possible links between spiritualism and spirituality and ancient and contemporary sport, the Olympic Games in particular. In the final part of the text I call attention to potential ethical foundation of sporting activity treated as a form of specific spiritual mission marked by spiritual features typical of spiritualism. This is a mission whose advocate is Andrzej Pawłucki inspired - in this regard - probably by Coubertin. Its axiological, that is to say ethical message takes the shape almost of Kantian categorical imperative. Since it assumes exceptionless necessity of spreading by athletes and other people connected with sport an objectively conceived and at the same time universal good with an intuitive overtone among all people, especially among these who will come into direct or indirect contact with them as contestants or spectators of events in variously understood sporting arenas and beyond. This good might be conceived as an unspecified good of Platonic perspective. However, it does not have a universal dimension which it had in Plato's and Kant's philosophies, because A. Pawłucki matches it up essentially to Catholic personalism. Incidentally, I leave aside in my analyses the associations between psychology and spiritualism and spirituality in relation to sport because I do not have adequate qualifications as a psychologist.

It follows from the abovementioned argument that spiritualism in its philosophical, religious (or, in a narrower sense, theological) interpretation contradicts - with some exceptions (ancient Olympic Games, sports in pre-Columbian cultures North American, Mesoamerican and South American natives, martial arts) enhanced status or affirmation of sensuality, corporeality, fitness, physical perfectionism, physical culture and variously understood sport.

Spiritualism according to its popular interpretation means spirituality. Qualities which are ascribed to that notion in particular societies can be determined on the basis of empirically oriented sociological research. They make it possible to determine various ways of interpreting and understanding that notion as well as views and attitudes connected with it.

Even without sophisticated empirical research it is possible to establish - on the basis of numerous contacts, heard statements or moves of intuitive, hypothetic qualities - that usually it is popularly assumed that spirituality is connected with deepened mental experiences of a higher order which have not so much cognitive but rather emotional, feeling character. Hence some activity of autotelic qualities appears. It consists of, among other things, aesthetical experiences or moral motivations, and it intuitively subordinates one's own private, individual interests to a super-individual good which is intuitively experienced and regarded as a manifestation of spirituality. This refers to realization of views, ideas connected with sublime love, justice, honesty, variously understood good of the whole society, an ideology of humane character. It is assumed for example that attitudes full of sacrifice - for example those connected with aesthetics and morality of the period of Romanticism, are saturated with emotionality and spirituality; that autotelic, ideological assumptions of humane, religious orientation - which are simultaneously connected with 
realization of various forms of highbrow culture, art, literature and correspond to social, national, group, family or patriotic needs - and their fulfilment are also saturated with spirituality.

Thus, spirituality in the popular sense of the word is supposed to be connected with striving for realisation of values which are at the top of internalized and approved hierarchy of values.

\section{Spiritualism versus the Olympic Games}

Emotional experiences concerning contemporary achievement-oriented (Olympic, professional, spectacular) sport are strictly connected - not only from the popular viewpoint - with mass culture. It creates values of - "epidermal" - not symbolic - character. Hence their reception is superficial in the sense that it is not attributed with manifestations of highly evaluated spirituality. Of course, contestants, spectators and other individuals connected with sport experience strong emotions. However, these concern rivalry, and the emotional overtone of that rivalry can be strengthened by social, economical and political circumstances (nota bene it seems that there is no inter-religious rivalry in that respect).

Sporting activity of achievement-oriented (professional, Olympic, spectacular character) is first of all exposition of rivalry and striving for variously understood sporting success (resulting from measurable or discretionary criteria). This refers to winning a competition or gaining another expected place as well as to other forms of satisfaction, such as financial gratification or social (political, ethnic, professional) recognition. Spirituality is here neither an aim, nor an expected value - it constitutes rather an additional or redundant quality. A competitor focuses his/her attention first of all on the main aim assumed in planned or current rivalry. Emotional sensations which are experienced by athletes before, during or after competitions testify to mental and emotional stress which accompanies sports combat.

It is also difficult to associate spirituality or spiritualism with sport for all - like, for example, that of health-oriented character - sport of the disabled, physical education, sport of playful character or physical recreation. That difficulty results from the fact that neither spiritualism, nor spirituality inspired physical activity in the abovementioned fields; neither spiritualism, nor spirituality are the outcome of activity in the realm of sport for all.

An exception in that respect is constituted by some experiences connected with recreational forms of tourism mediated through achievement-oriented sport. During mountain hiking and mountain climbing there can appear manifestations of deepened spirituality characteristic of the object of spiritualisation of nonreligious, quasi-religious or strictly religious qualities. This refers - as in the work of Mariusz Zaruski among other things to aesthetisation of nature, ascribing it e.g. with architectonical qualities of the Gothic style or with artistic and cultural qualities which are to initiate and deepen spiritual experiences of the extravert and the introvert kind (Krawczyk, 1970; Kosiewicz, 2004, pp. 396-404; Gołaszewska, 1994, pp. 234-250; Zaruski, 1958).

It is also connected with sacralisation of nature of pantheistic or panentheistic kind. In the first case a tourist, a wanderer, a Tatra mountaineer, an Alpinist or a Himalayist feels that a deity - for example an indefinite or a definite, variously conceived spirit of the mountains - disperses and manifests itself in an exhaustive way in nature. In the second case, s/he feels that the abovementioned deity does not lose its autonomy since it exists both in nature and beyond it. Spirituality manifests itself by ascribing the mountains with charm and other qualities of temples: churches, cathedrals, basilicas, synagogues, shrines, but also by experiencing supernatural - although non-religious - properties of nature, which is connected with a feeling of communion with a divine being, which - because of emanating eternity, unchangeability, ominous and untamed power - causes, as in Soren Kierkegaard's and Rudolf Otto's conceptions of God - trembling and fear of the unknown (Kosiewicz, 2004, p. 300; Otto, 1968; Kierkegaard, 1982). 
The Hellenic Olympic Games were a highly spiritualised form of sporting rivalry - including also rivalry in the field of art, and especially in the field of theatre. They were one of numerous forms of religious cult - of worshipping chosen gods from the Olympic pantheon. They were manifestations of spiritualism.

The Olympic Games of ancient Greece were first of all a religious event and a connected sacred experience constituted the highest and autotelic value, constituted an end in itself. Both the sports agon and the theatrical agon (which was connected also with other forms of art and bore witness to Greek paideia, Jaeger, 1964) were manifestations of subordination to principles of soteriological (that is, connected with salvation) ethics which were in force in the religion of the time. The Olympic Games highlighted advanced, significantly deepened spiritualisation of sport. During the Games their participants - contestants and spectators - sought favours from selected gods facilitating possible salvation, achievement of eternal happiness in the afterlife.

Fitness and physical effort, sporting perfectionism, and advanced specialization were not ends in themselves, but only means - they enabled achievement of an end of strictly spiritualist, religious character.

Thus in that case there was a far-reaching convergence - or even an organic unity - between spiritualism and the Games, which constituted a Greek contribution to achievement-oriented, professional, spectacular sport. That anthropological-cultural cohesion disappeared together with the fall of ancient Olympic agon.

Admittedly, the modern Olympic Games refer to many elements of the abovementioned agon. Nevertheless, they have, unlike it, a secular character - they broke away from the religious background, they departed from principles and assumptions of religions of ancient Greeks and Romans.

On the other hand, Coubertin - who knew power of influence of religious beliefs and institutions aspired (referring to religious patterns) to make the Olympic movement and the modern Olympic Games a peculiar church, a religion in a broad meaning of the word. Hence an important role is played there by specific, secular but solemn forms of cult - among others in the form of ceremonies of opening and closing the Games. This refers also to the doctrine (that is, peculiar teaching) in the form of the neo-Olympic ideology including pedagogy of sport initiated by the French baron ("Pedagogie sportive" published in 1919), which gave origin to currently developing Olympic education. It refers also to institutional structures of the Olympic movement, which are centralized like in Catholicism, have quasi-sacred character and consist of the unquestionable oracle - the International Olympic Committee - and of national Olympic committees, which are subordinated to it. Thus, in spite of cardinal differences, they constitute a replica of Vatican and national churches.

The Olympic movement - and especially the Olympic Games - constitute a significant and highly spectacular attempt at spiritualisation of corporeality, physical effort, sporting activity, which has a new, non-philosophical, non-religious, non-theological character. This can be proof of aspiration to make the modern Olympic Games something more that sport - similarly as ancient agon was something more than sport.

Baron Pierre de Coubertin - similarly to his proponents and followers - wanted to attribute the Games with such values which would go beyond strictly physical competition between contestants regulated by rules characteristic for given sports. This was to be achieved first of all by ceremonies of opening and closing the Olympic Games and the award ceremony (Parry, 2007, p. 209). They were attempting to be saturated with sacred qualities, with secular spiritualism approving bodily-sports effort, to be spiritualised with oaths, incantations and aesthetic endeavours.

Jim Perry writes that Coubertin wanted to make modern Olympians "the religio athletae" and that he treated sport as if it was a "modern religion" (Parry, 2007, pp. 205-207).

However, artistic performances taking place during the abovementioned ceremonies usually come from popular culture - they are adjusted to the level of aesthetic and cognitive reception of a stadium fan and 
an average and unrefined recipient of mass culture. Those ceremonies have character of stage performances interlarded with mass and simplified - although dazzling with splendour of décor, costumes and props choreographic routines with some serious but laconic speeches by persons representing the IOC, the proper national committee and representatives of contestants and judges taking on their behalf Olympic oaths corresponding with their status.

Directors of those unique performances aspire to arouse cheerful applause and admiration for those gigantic stadium spectacles and for thousands of their participants.

Undertakings of that kind are, however, situated beyond religious culture, beyond sublime spiritualism. They aspire to popularly understood spiritualism, but they do not achieve even that. They are only customary spectacles, which are different in each case and are more or less successful from a commercial and aesthetic point of view.

However, their ceremonial and ideological rank is lowered by clear falsehood of evaluation of importance, power and range of influence of the Games. Representatives of the IOC and organisers of given Games emphasise with exaggerated pomposity and optimism that the Olympic Games influence the current state of spirit and emotions in the world, whereas the world, states, nations, individuals function during them according to their everyday, economic, professional, school, family, religious, artistic or socio-cultural rhythm. Offices, universities, schools, nursery schools, armies, hospitals, concert halls, theatres, cinemas function and are filled with people as usual. The same applies to TV channels and radio stations - except for the one or two, which transmit the course of the Games in a given country. Politicians - except for the hosts - usually are not bothered about the Games. This remark applies in particular to the politicians who want to provoke tensions, conflicts, wars, boycotts or stimulate terrorist attacks.

The majority of sports (and contestants) - including the most popular, spectacular and profitable ones - are absent or almost absent during the Games. The Olympic Games are not anything unusual - they are neither the supreme end, nor the highest sports value for the majority of contestants.

During the Games it is proclaimed that they are something unique in the life of youth of the world that they are participated in by the best of them. But this is wrong not only in the context of the sporting milieu, but first of all if referred to young people who do not go in for top sport, who are interested first of all in learning, medicine, business, philosophy, artistic career, etc. - that is, to young people who find fulfilment outside of top sport. They constitute the overwhelming majority of the youth as such.

Spiritualisation based on false premises is not true spiritualisation - it is, as a matter of fact, a deformation of reality which can lead to alienation and become a kind of opium of the people - that is, opium of the youth who receive the world in a one-sided way influenced by ideology and propaganda.

\section{Spiritualism versus the ethical mission of sport}

Attributing the contemporary Games with some additional, non-pragmatic, disinterested, missionary, humane qualities with qualities and functions which are to be spiritual in the popular sense of the word or even spiritualist is, as I suppose, a mistaken move, a misinterpretation.

The Olympic combat is first of all about variously conceived success. From the viewpoint of competitors, coaches, sports unions, national Olympic committees and fans the remaining expectations, aspirations, dreams and needs is something of secondary or tertiary importance.

The Olympic Games are participated in only by those competitors who have either taken an awarded place in eliminations or have achieved a required minimum - a measurable or discretionary result enabling them to enter the Games. They are not admitted to the Olympic team because of any specific traits of character - like e.g. honesty, modesty, nobleness, disinterestedness or commitment to popularisation of the fair play principle. 
For example for achieving a good placing (from first to third) Polish Olympic athletes - similarly to their rivals from other countries - gain not only a high financial reward but also a monthly fee which is paid to them from the age of 35 up to the end of their lives. Nota bene other places in competition are not taken into account by the Polish Olympic Committee, because - in the opinion of its authorities - athletes who gained lower placings are quickly forgotten.

The abovementioned situations do not confirm the opinion that the Olympic Games are something more than sport. They merely verify - that is, confirm or corroborate - a thesis that competitors practise a profession which is highly paid by governmental and non-governmental institutions of a given country and by private sponsors - especially after securing a required top place among the best. Olympic sport - similarly to other forms of top, professional, spectacular sport - manifest quite clearly reductionist properties and limit the significance and range of influence of humane and spiritual claims.

A transparent move away from autotelic, strictly spiritualist, religious values which were characteristic for the Greek Games, or even a breaking off from them is taking place. There appears clear instrumentalisation of Olympic sport.

Attributing sports and the athlete with ethical missions is also a misinterpretation. Olympic sport (including properties of achievement-oriented, professional, spectacular sport) - similarly to other professional corporations - is based on deontological ethics concerning persons who are professionally connected with sport.

Thus, it is not the supreme aim of Olympic contestants to propagate or persuade other persons to obey ethical principles connected with their profession. It would be pointless, since those others do not practise that profession).

Robinson in one of his subsequent depictions of spiritualism informs that the working definition ${ }^{1}$ presented by him is comprised of three parts, that is

"Awareness and appreciation of the other (including the self, the other person, the group, the environment and, where applicable, deity). The capacity to respond to the other. This involves putting spirituality into practice, embodying spirituality, and thus the continued relationship with other. Developing significant life meaning based upon all aspects of awareness and appreciation of and response to the other" (Robinson 2007a, p. 24).

When commenting on this statement, Perry notices that Robinson wants to demonstrate that in fact Coubertin did not treat Olympism - examining this question from a formal point of view - as a typical form of religion which intended to compete with Christianity or with Buddhism for people's hearts and minds. As a matter of fact, it was the spirituality in the form of moral movement whose aim was to be potential subjective perfection (Parry, 2007, pp. 209-210). I think that in connection with it - despite noble intentions we face colloquial and postulational form of spirituality which contains solely sententious overtones.

However, the eminent thinker and theoretician of physical education following the French Baron, Andrzej Pawłucki (2008, p. 1), who follows the French baron, attributes professional athletes with some additional ethical tasks going beyond the main aim of their basic gainful activity, which are supposed to be the most important. He points out that, regardless of their choice and knowledge, they have a vocation to realise missionary aims in order to promote moral good as such.

${ }^{1}$ Robinson making another attempt of defining the term "spirituality" in a provisional way (presented rather in a spirit of spiritualism) states that it concerns,

,the practice and outworking of the spirit and the ways in which it is developed, with its different aspects and relationships connected, sustained and understood. As we shall see, this may involve the spirituality of an individual or that which is developed in and through the disciplines and practices of a group or team. It is often a combination of both. Essentially then, spirituality is relation and action centred, and about making connections with these different aspects of life” (Robinson 2007a, p. 24). 
He alludes in this case (probably unintentionally) to the ethical views of Socrates, who treated man mainly as homo ethicus. Socrates treats philosophy as wisdom or knowledge connected first of all with moral virtue. This one-sided form of ethical intellectualism and archaic and superficial anthropological reductionism cannot be supported any more from the point of view of modern anthropology and the philosophy of human being.

Nota bene the notion of good has intuitive character. Admittedly we have - according to Plato - an intuitively perceived idea of good of universal character (which is placed on the highest position in the hierarchy of eternal ideas). It is a property of that conception of good that a countless number of more or less contradictory specifications of the idea of good, which often come into radical conflict with each other, confirm both objectivity and universality of good as an ideal being according to the abovementioned interpretation.

Taking that into account the contestant realises such good (moral principles) which is experienced by him or her and the professional code facilitates its realisation from the viewpoint of assumptions on a given sport or a definite sport movement (like, for example, the Olympic movement). Thus, any mission, vocation or spreading any particular clear and absolute moral principle is out of question. That kind of spiritualisation of sport - in spite of noble intentions of the eminent theoretician of physical education and pedagogue - is an obvious and baseless misinterpretation.

An attempt at spiritualisation of the contemporary Olympic Games through introducing moralistic and excessive requirements for athletes - expectations going beyond their profession - is an artificial and, fortunately, marginal phenomenon.

It is admittedly a noble attempt, but it is situated beyond the everyday and Olympic agon. That spiritualisation refers, however, to the originator of that idea himself, since it takes place in him.

On the one hand, he tries to enrich knowledge of possible interpretations of moral behaviours and assumptions in Olympic relations in a disputable way. On the other hand, he exerts a negative influence not only when he recognises his own views on that issue as the only right ones, but especially when he tries to impose them on others - to force their acceptance.

We have to do with this when assessing journalists' commentaries accompanying the Games (which are, nota bene, typical for relations from national and international championships). Their assessments are highly negative because of the noticeable scarcity of moral considerations. They are - in Andrzej Pawłucki's opinion (ibid., p. 1) - proof of the "ignorance of sports writers".

That criticism is exaggerated and the expectations are excessive, because the sports journalist is not professionally prepared for considerations on morality. Moreover, it is obvious that $\mathrm{s} / \mathrm{he}$ may not know controversial views of one of many academics. Neither must s/he share them or - the more so - spread them in his/her commentaries.

Journalists fulfil different social needs than scientists (or politicians, sailors, chroniclers, playwrights and mill workers, for that matter). They are professionals and they adapt to the social expectations of employers, fans, contestants and other persons interested in sport, as well as those who are not connected with sport. All journalists have the right to perceive sport in their own way, to treat it as a manifestation of mass culture. They are not - unlike Catholic priests - professional moralists. Neither are they called upon for - as Immanuel Kant and every citizen of his realm of ends were - the realisation of some indefinite categorical imperative suspended in the starlit sky, which makes sport only its instrument and accidental carrier. It is not that transcendentally situated imperative, justified in a formal and abstract way, which is the most important there, but particular human activity leading to fulfilment of definite needs - like, for example, those of an aesthetic and artistic kind in the case of art, of the medicinal kind in medicine, the transport-related kind in railways or airlines, and the competitive kind in top sport. Accompanying moral 
assumptions are not the supreme aim but an additional element which may - or may not - help to achieve the aim characteristic for a given profession - like e.g. that of a painter, a physician, a pilot or an athlete.

\section{REFERENCES}

Baker, W.J. (2000). Gods and Games-Religious Aspects of the Modern Olympics. In If Christ Came to the Olympics. Sydney, Australia: UNSW Press.

Coakley, J.J. (1986). Sport and Religion, Is It a Promising Combination? In Sport and Society, $3^{\text {rd }}$ Edition. St Louis: Missouri Times Mirror/Mosby, College Publishing,.

Eitzen, D.S., Sage, G.H. (1989). Sport and Religion. In Sociology of North American Sport, $4^{\text {th }}$ Edition.

Enger, D.J. (2003). Should Sports be Used as a Tool for Ministry. At http://www.tiu.edu/cmx/seniors03/enger.pdf

Gołaszewska, M. (1984). Rzeczywistość w sytuacji para artystycznej /Reality in Para-Artistic Situation/. In Estetyka rzeczywistości /Aesthetics of Reality/. Warszawa.

Guttman, A. (1992). From Ritual to Record. In Sport and Religion, Shirl J Hoffman (Ed.) Champaign, Illinois: Human Kinetics Books.

Jaeger, W. (1964). Paideia. Warszawa.

Judycki, J. (1997). Duch - materia /Body - Matter/. In Herbut J. (Ed.) Leksykon filozofii klasycznej /Lexicon of Classical Philosophy/. Lublin: Towarzystwo Naukowe KUL.

Kierkegaard, S. (1982). Bojaźń i drżenie. Choroba na śmierć /Fear and Trembling. Sickness unto Death/. Warszawa: PWN.

Kosiewicz, J. (2000). Bóg, cielesność i miłość /God, Corporeality, Love/. Warszawa: „Aletheia”.

Kosiewicz, J. (2004). Filozoficzne aspekty kultury fizycznej i sportu /Philosophical Aspects of Physical Culture and Sport/. Warszawa: Wydawnictwo BK.

Kosiewicz, J. (2005). Tourism and Sacrum. European Journal for Sport and Society. Münster.

Kosiewicz, J. (2006). Rekreacja fizyczna w zwierciadle filozofii. In Dąbrowski A. (Ed) Zarys teorii rekreacji ruchowej. Warszawa: Almamer.

Kosiewicz, J. (2007). Helleńskie (religijne i filozoficzne) źródła chrześcijańskiej koncepcji ciała - od orfizmu do gnozy /Hellenic (Religious and Philosophical) Sources of Christian Conception of the Body - from Orphism to Gnosis/. In the same, Myśl wczesnochrześcijańska i katolicka wobec ciała/The Body in Early Christian and Catholic Thought/. Warszawa: Witmark.

Kosiewicz, J. (2008). The Anthropological Background of the Philosophical Reflection on Nature and Tourism, European Journal for Sport and Society. Münster.

Krawczyk, Z. (1970). Natura, kultura, sport. Kontrowersje teoretyczne /Nature, Culture, Sport. Theoretical Controversies/. Warszawa: PWN.

Krokiewicz, A. (2000). Studia orfickie /Orphic Studies/. In the same: Studia orfickie. Moralność Homera i etyka Hezjoda /Orphic Studies. Homer's Morality and Hesiodus's Ethics/. Warszawa: Aletheia.

Otto, R. (1968). Świętość /Idea of the Holy/. Warszawa.

Pawłucki, A. (2000). Sport jako modernizm olimpijski /Sport as Olympic Modernism/, unpublished.

Perry, J. (2007). Spirituality: a working definition. In Sport and Spirituality. An Introduction. London and New York: Routledge, Taylor\& Francis Group, pp. 201-214.

Robinson, S. (2007a). Spirituality: a working definition. In Sport and Spirituality. An Introduction. London and New York: Routledge, Taylor\& Francis Group, pp. 22-37.

Robinson S. (2007b). Spirituality: a story so far. In Sport and Spirituality. An Introduction. London and New York: Routledge, Taylor\& Francis Group, pp. 7-21.

Saint Sing, S. (2004). Spirituality of Sport, Balancing Body and Soul. Cincinnatti, Ohio: St Anthony Messenger Press.

Zaruski, M. (1958). Na bezdrożach tatrzańskich. Wycieczki, wrażenia, opisy. /In the Tatra Wilderness. Excursions, Sensations, Descriptions/. Warszawa. 
AUTHOR'S ADDRESS: Jerzy Kosiewicz

Department of Philosophy, Chair of the Social Sciences

Josef Pilsudski University of Physical Education in Warsaw

34 Marymoncka str., 00-968 Warsaw, Poland

Email: jerzy.kosiewicz@awf.edu.pl 